\title{
The Challenges of e-Tailing in Employment Creation: Empirical Evidence from Nigeria
}

\author{
Emmanuel A. Iborida ${ }^{1}$, Bamidele S. Adeleke ${ }^{2}$, Geoffrey O. Ekoja ${ }^{3}$ \\ ${ }^{1}$ Department of Marketing, University of Nigeria, Enugu Campus \\ ${ }^{2,3} \mathrm{PhD}$ Scholars, Department of Management, University of Nigeria, Enugu Campus.
}

\begin{abstract}
As more and more manufacturers and retailers turn to e-tailing to increase profits and capture new customers, the emphasis on online shopping means more opportunities for web designer jobs and developer jobs, not to mention an increase in the number of marketing jobs and content roles. This paper investigates the retail sector contribution and strategies for job creation. The research is based on a wide and broad literature review of the latest trends in the Nigeria retail industry, followed and supplemented by quantitative research of the key retailers in the country. The work, among others things identifies the drivers of change and related factors that have a bearing and influence on employment creation based on the emerging opportunities and threats (e.g. Technology). The study also evaluates the effect of e-retailing on job creation in Nigeria and as well investigates the challenges for managing e-tailing in a developing economy. To achieve the spelt objectives, the study utilizes survey design; and data was collected though a self-administered questionnaire from a number of 302 respondents who were retailers in three selected open markets in Ibadan Metropolis, Oyo State Nigeria. Statistical technique software SPSS was employed to aid the data analysis. Having analyzed the data, the study found out that e-tailing has brought about changes in the ways people buys and this affects many traditional retail outlets. It was also discovered that $e$ tailing is still ineffective in Nigeria economy. The work among other things, recommends that brick and mortal retailers should strengthen their operations in order to continue being in business. The work in addition to that also advised that Nigeria manufacturers and retailers should go electronic so as to face the digital rivals created by e-tailers.
\end{abstract}

Keywords- e-Tailing, Brick and Mortal Retailers, Retailing Management, Employment Creation.

\section{INTRODUCTION}

In hindsight, many of the original predictions made at the dawn of the internet era have not become a reality. Retailers are not cannibalizing their own custom, virtual merchants www.ijaems.com do not dominate the market place, and the high street has not been put out of business. By contrast, other predications have come to pass: electronic intermediaries are playing an increasingly important role, "one-to-one" marketing has become a reality, prices are more competitive, and, perhaps most importantly, the consumer has become more powerful. By and large, consumers have responded enthusiastically to these innovations, and online retail sales have grown significantly over the past 15 years and are predicted to continue rising into the future (Doherty \& Ellis-Chadwick, 2010).

Generally, the Internet has changed the way many consumers shop, not just in the digital domain, but also in the physical world. Imagine a prospective book-buyer who spends an hour or two browsing the aisles of his or her favorite neighborhood bookstore, and who also perhaps spends some money on a coffee at the store. In addition, this prospective customer makes a mental note of interesting titles which he or she might likely buy. Later that evening, this same person gets home, and places an online order for the very same books at an online bookstore.

The great advantage of a retail store is that the customer can pay for the item and receive it immediately. Other forms of retailing tried to match this great advantage by offering the convenience of shopping from home. Thus, mail order catalogues emerged, often in conjunction with large retail chains (for example, Sears) (Kalyanam \& McIntyre 2002). When it was recognized that the mail order catalogue was an effective means of presenting products to customers, televised shopping channels emerged which exploited the medium of television to enhance and convey details of the products to customers. The advent of credit cards also made this process of payment even easier. It also made it possible for the customer to pay for an item, even though the customer did not, at the specific time of the sale, actually have the money in hand to pay for it. Another practice also set the stage for online retailing: cross-border shopping. In the United States, where every state and region may have a different rate of sales tax, it is common for customers to drive across a state line in order to purchase items at a lower

Page | 1006 
sales tax rate. In Europe, the same may apply by crossing national borders to purchase items such as liquor, cigarettes or perfume where tax or duty is lower: customers enjoy taxfree shopping. Though in Nigeria the experiences in the US and Europe are not similar but as soon as online shopping became available, customers immediately recognized the great advantages of being able to ignore state or national boundaries in making appositive choices (Babbie, 2008).

Ernst and Young (2012) explain that the e-tailing industry is expanding rapidly with strong early life cycle growth. In U.S. between 2003 and 2008 industry revenue rose at a CAGR of $20 \%$. Even in 2009, when total retail sales fell $7.2 \%$, online sales grew $4.3 \%$. Despite the recent economic slowdown, the e-tailing sector enjoys continued growth due to increasing worldwide internet penetration and other factors. Long term trends driving increases in online activity remain positive. We expect such trends to support continued expansion by internet companies despite a weak economic environment. Coming to Nigeria scenario, the organized retailing is showing a tremendous growth in recent years. And proportionately the electronic retail growth of Nigerian market as estimated by Euro-monitor report stands close to $18 \%$ CAGR and in value term it is going to touch N5 billion by 2015 from N150 million in 2005 (Hutchings, 2015).

Traditional Bricks and Mortar re-tailers (B\&M), realizing the importance of online sales and acquiring a Bricks and Clicks (B\&C) platform both as a defensive strategy and to access market opportunities. With a $43 \%$ share of total Mergers \& Acquisitions (M\&A) volume between 2005 and 2009, B\&M retailers have been the largest category of acquirers. An acquisition of an e-tailer provides B\&M retailers with a multi-channel retail format, helping them overcome store location limitations and access a wider consumer base. Existing e-tailers are also important acquirers, with a $32 \%$ share of total deal volume over the same period. E-tailing M\&A is driven by large e-tailers' aggressive product diversification strategy involving the acquisition of specialty e-tailers to augment product and service offerings. There has been some geographical expansion through M\&A, and this is expected to increase (Haubl \& Trifts, 2000).

Achieving full employment, decent work and sustainable livelihoods is the only way to improve living standards and ensure a dignified existence for all Nigerians. The retail sector, with its large footprint in both urban and rural areas, has the potential to create more sustainable jobs in Nigeria, something that is widely recognized as essential for the country's political and economic stability. But nevertheless, there are many factors at play, among them the phenomenon of 'jobless growth', a widening skills gap, www.ijaems.com continual technological changes and shifts in consumer behavior due to the advent of e-tailers. This has resulted to the decline of many brick and mortals retails firms thereby encouraging rising unemployment. It is against the foregoing issues that this paper intends to evaluate the challenges of e-tailing in employment creation with empirical evidence from Nigeria. The study objectives are to:

i. Identify the drivers of change and related factors that have a bearing and influence on employment creation

ii. Evaluate the effect of e-retailing on job creation in Nigeria and

iii. Investigate the challenges for managing e-tailing in a developing economy.

\section{REVIEW OF RELEVANT LITERATURE}

\subsection{The Concept of e-Tailing}

According to Turban (2006), e-tailing is defined as retailing conducted online, over the internet. Wang (2002) has provided a broad definition of e-tailing by defining it as the selling of goods and services to the consumer market via the internet. Zeithaml (2002) has defined that the success of etailing depends on the efficient web site design, effective shopping and prompt delivery. The other e-store services are delivery on real time, return and replacement process, period of filling out online orders form, speed of response time to e-customers queries.

Ratchford (2001) have told that through Internet, consumers can gather information about merchandise and they compare a product across suppliers at a low cost Rao (1999), E-commerce offers increased market activity for retailers in the form of growing market access and information and decreased operating and procurement costs. Consumers are getting smarter in using e-tailers (and online search engines and agents) for convenience and comparison shopping. Guttman (1998) describes several unique elements make online shopping different from the traditional in-store retail model. Besides offering convenience and expanded product variety, the online model also makes it easy for consumers to access and compare data from multiple sources. Meeker (1997), retailers might cry foul, but the new shopping paradigm they have to face is that as premium customers begin to accept the e-tail alternative in larger numbers.

\subsection{Growth Drivers of e-Tailing:}

The key global e-tailing drivers includes, increasing broadband penetration Expansion in e-tailing services is closely correlated with an increase in broadband 
penetration. Continuing growth in broadband uptake, as well as faster connection speeds, provides support for growth at internet companies. Continuing increased broadband penetration will remain a key factor in the ability of e-tailers to acquire market share at the expense of general retailers (Varadarajan, and Yadav, 2002)

\section{Better technology = Better services:}

Increased internet connectivity and lower costs of computer processing power are making the mechanics of conducting an e-tailing business easier. The advent of sophisticated software and supporting hardware has allowed e-tailers to study consumer behavior more efficiently, facilitating targeted sales and increased product cross-selling. This gives e-tailers a major and increasing competitive advantage compared to their B\&M competitors. Extensive product search, instant product comparison, wide scope of brand selection, easy transacting, and free shipment and flexible sale return policies (within 1-3 weeks time) are more petals of this service flower.

2. Increased Product Diversity:

With e-tailers better understanding customer requirements, online shopping has responded by providing a greater diversity of products and services, include more specific, niche offerings. In the case of a number of very small specialist markets, regarded as either too small or specific for traditional retail outlet viability, the development of online retailing has improved their commercial feasibility, increasing the range of products available online.

3. More Confidence in Payment Options:

Another crucial driver has been improvements in processing payments for transactions. For example, Amazon allows payment using either credit cards or electronic funds transfer. eBay has implemented PayPal, through which shoppers run a personal online account, enabling them to shop online without disclosing their financial details to retailers. Credit card providers have made advances in security, and increasing consumer familiarity has also improved confidence.

4. Reducing the Incremental Mark-Up:

Majority of Intermediaries are feeling the pinch from manufacturers as the Internet threatens, disintermediation in channel networks allowing the manufacturers to sell direct to the consumers. It is possible to enjoy the cost advantages of direct selling while still maintaining an effective and economic customer service without passing the expense for either on to the consumer. Such a business model sounds too good to be true yet its configuration is simple. The manufacturer initiates a web strategy allowing it to sell direct to the customer reducing the incremental mark-up at intermediate levels.

\subsection{Drivers of Change in Retailing: The Advent of e- Tailing}

1. Technology

Without doubt the greatest driver of change in the retail sphere is the emergence and growth of E-Commerce. In 2012, Amazon.com climbed into the top 10 largest retailers in the USA at the expense of powerful legacy brands such as Kmart, Sears and JC Penny (McKinsey, 2012b). According to Plunkett Research (2014), growth in online shopping in the United States has been driven by two factors. First, the number of fast Internet connections in U.S. homes and businesses leapt to more than 90 million by 2013, plus 180 million wireless connections, which makes buying online faster and more interactive. Secondly, service offerings by online giants like Amazon and dual channel approaches of traditional retailers such as Home Depot and Wal-Mart, are creating value offerings that are difficult to match. Furthermore added convenience and value is being created by $\mathrm{M}$-commerce that is shopping via mobile devices including smart phones and tablets. e-Marketer data estimates that $\mathrm{m}$-commerce totaled $\$ 41.68$ billion in the U.S. during 2013, a $68.2 \%$ increase over the previous year.

\section{Changing Buying Patterns}

Recession creates habits which are difficult to change. Many people, regardless of wealth, are expected to pursue increasingly polarized shopping decision processes. For categories these shoppers care deeply about, it is expected that a rise in premium products that are tailored to their specific needs will be experienced. For product categories where consumers are more indifferent, it is expected that there will be a rise in the extreme value segment (PWC, 2012). Price Waterhouse Coopers (2012) identified four shifts in consumer behavior namely:

a. The biggest change in behaviour was for consumers to seek out promotions and special offers on groceries.

b. Next biggest change in buying behaviour was to switch from premium brands to cheaper brands and private labels.

c. Fewer consumers changed their retailers for the purposes of saving money. However, most of those under more trying financial circumstances who did change would stay with the new retailer to continue to 
save money even after their financial circumstances improved.

d. Finally, consumers purchased fewer quantities of each item. This however was the most likely change to revert back to previous behaviours under more favourable financial conditions.

\subsection{Business Activities and Employment: The Nexus}

Increasing employability and obtaining of gainful employment are the goals of every people in any country both student intern and job seeker. Internships, paid or unpaid, serve as a rite of passage to a job or a career, and they do play an important role for their constituents (students/interns, employers and academic institutions), the nation's society, labour force and economy. From the employers' and academic institutions' perspective, there are numerous benefits with low or non-existent costs. From the student interns' perspective, when comparing the costs and benefits of unpaid to paid internships, it appears that the unpaid ones come with high opportunity costs and contribute substantially less to the interns' success and goal of securing gainful employment.

Additionally, the current setup allows for some employers to take advantage of the lack of strict monitoring and enforcement of the labour laws, which results in intern exploitation. From the societal and economic perspectives, unpaid internships restrict access and opportunity to good jobs for people of disadvantaged socioeconomic backgrounds, constrict social and economic mobility, and have a negative impact on the economy at both the microeconomic and macroeconomic levels (Pologeorgis, 2012).

\section{5. e-Tailing, Traditional Retailers and Employment Situation}

Since the advent of e-retailing in Nigeria, the success of brick and mortal (B\&M) retailers has continued to be in shambles with many losing customers to the electronic shops and online masters. Most of the individual owners of traditional retailers lose their jobs as a result of mismatch between them and the e-tailers who are most often global in nature. The protracted weakness in consumer spending has continued to threaten $\mathrm{B} \& \mathrm{M}$ retailers with significant numbers having filed for bankruptcy. Recent B\&M bankruptcies are expected to drive more consumers towards e-tailers. According to the Centre for Retail Research, UK consumers spent $£ 38$ bn online in 2009 , a record high $10 \%$ of total retail sales.

\section{METHODOLOGY}

The research adopted a "survey method" and design. The area of this study consists of Ibadan metropolis, in Oyo state, Nigeria. The population of the work consists of the retailers in selected three open markets in Ibadan. They are Mokola, Dugbe and Aleshinloye Markets. These markets were selected because they constitute the three open markets that have almost all the merchandises. They were selected through a convenient sampling technique. The total populations of the retailers in these selected markets were 2532. The researcher determined the size of the sample. A total of 302 sample was drawn from the study population. Data for this study were collected mainly from primary source through questionnaire that was self-administered. The answer options for the questionnaire were developed using Likert scale with: SA - Strongly Agree, A - Agree, U - Uncertain, D - Disagree, SD - Strongly Disagree. Content and face methods of validity were done on the instrument. Also, the value 0.86 was gotten from reliability test analyzed through the method of Cronhbar Alpha.

\section{DATA PRESENTATION AND ANALYSIS}

Of the three hundred and two (302) questionnaires administered, two hundred and eighty eight (288) representing $95.4 \%$ were returned and found good for the data analysis.

\subsection{Test of Hypothesis}

The second objective of the study was subject to test of hypothesis to determine the validity of the respondents.

HO: e-retailing do not affect retailing job creation in Nigeria

HA: e-retailing affect retailing job creation in Nigeria Regression model: $\mathrm{Y}=\alpha=\beta \mathrm{X}+\mu \ldots$ (For all observations $\mathrm{i},=1,2 \ldots \mathrm{n})$

Where $\mathrm{Y}=$ Retailing Job Creation

$$
\begin{aligned}
& X=\text { e-Retailing } \\
& \mu=\text { error term of random variable } \\
& \alpha=\text { a constant amount } \\
& \beta=\text { effect of } X \text { hypothesized to be positive }
\end{aligned}
$$

Hence, the regression (predict) equation will be $\mathrm{Y}=$ $108.011+1.212 \mathrm{X}$ 
Table.1a: Model Summary

\begin{tabular}{|c|c|c|l|l|}
\hline Model & $\mathrm{R}$ & R Square & Adjusted R Square & Std. Error of the Estimate \\
\hline 1 & $.711^{\mathrm{a}}$ & .711 & .963 & 29.15133 \\
\hline
\end{tabular}

a. Predictors: (Constant), e-Retailing

Table.2b: ANOVA ${ }^{b}$

\begin{tabular}{|ll|l|l|l|l|l|}
\hline Model & & Sum of Squares & Df & Mean Square & F & Sig. \\
\hline 1 & Regression & 20171.151 & 1 & 20171.151 & 17.211 & $.003^{\text {a }}$ \\
& Residual & 2712.049 & 287 & 928.350 & & \\
& Total & 22883.200 & 288 & & & \\
\hline
\end{tabular}

a. Predictors: (Constant), e-Retailing

b. Dependent Variable: Retailing Job Creation

Table.3c: Coefficients ${ }^{a}$

\begin{tabular}{|ll|l|l|l|l|l|}
\hline \multirow{2}{*}{ Model } & \multicolumn{2}{|l|}{ Unstandardized Coefficients } & Standardized Coefficients & & \\
\cline { 3 - 5 } & & $\mathrm{B}$ & Std. Error & Beta & T & \multirow{2}{*}{ Sig. } \\
\hline 1 & (Constant) & 108.011 & 47.849 & & 3.113 & .061 \\
& EI & 1.212 & .416 & .939 & 3.118 & .005 \\
\hline
\end{tabular}

a. Dependent Variable: Retailing Job Creation

\subsection{Result Findings}

i. The drivers of change and related factors that have influence on employment creation

Previous extant studies (Ratchford, 2001; Turban 2001) as well as the personal observations in Nigeria business domain revealed that technology and consumer buying patterns changes have been the two major factors that have influence employment creation in Nigeria. The advent of technology as well as more sophisticated buying power of consumers have made them to make dramatic decision which favour e-tailers. These, on the contrary, affect the traditional brick and mortal retail organizations thereby leading to low sales, declining profit, shutdown of business and loss of jobs.

\section{ii. The effect e-retailing on job creation in Nigeria.}

Having analyzed the data from the questionnaire using regression analysis to examine if e-retailing activities affect job creation in Nigeria. The Tables 1a, b \& $\mathbf{c}$ revealed that the regression result shows the existence of significant result on the variables $\left(\mathrm{R}^{* *}\right.$ calc $=0.711>$ at $\left.\mathrm{p}<0.05\right)$. The significant level was found to be 0.03 , and due to this we reject the null hypothesis and accept the alternate one which states that e-retailing affect the retailing job creation in Nigeria.

\section{CONCLUSION AND RECOMMENDATIONS}

There are several important lessons to be learnt in the transition from bricks and mortar retail to the digital e-tail world. While skills like speed, differentiation, and branding are equally if not more important in the digital world, it is the ability to transform core operations and practices to this new medium which might make the difference between success and failure. Online shopping is now an everyday part of most peoples' lives. From the perspective of the here and now, and looking forward, there is plenty of evidence to suggest that this internet-enabled revolution has much more life in it yet.

The revolution has moved from a phase in which the innovation and ideas were primarily flowing from the supply-side to one in which the consumer, from the demand-side, is empowered to direct the way in which the revolution unfolds

i. It is recommended that traditional retailers have to critically consider the migration to a digital domain, and address challenges that might impede a smooth transition.

ii. B \& M retailers need to make a Go / No-Go decision on whether they should have an e-tail storefront. If 
they go ahead with establishing an online presence, the main challenges will be for operations and marketing. Initial research suggests that the addition of an e-tail channel might be relatively easy if the company also had cataloging experience.

iii. Furthermore, retailers can use their e-tail storefronts to capture valuable customer demand data, and conduct pricing and promotional experiments. Consumers are often willing to spend significant time in personalizing their experience, and this clear opportunity to 'hear the voice' of the customer is greatly facilitated by several off-the shelf tools that capture and analyze data from online visits. These tools are also being provided by web-store hosting services like Yahoo. Such data can provide a good basis for forecasting future demand patterns and customer preferences. In a typical retail environment, such data is available but extremely hard to distill and analyze, and several leading retailers are faced with challenges in handling the data glut.

iv. Traditional retailers can significantly enhance the instore experience throughout the retail network to attract customers. Through carefully managed convergence, e-tail storefronts and catalogs can be innovatively deployed to increase awareness and drive customer demand.

As the costs of advertising on the Web increase (leading to an increase in customer acquisition and retention costs), several innovative retailers have also begun to use direct marketing and traditional media channels to get their online presence across to customers. Thus a lot of synergies can be achieved by combining some of the core retailer strengths with an online business channel. Only time will tell if these strategies succeed in exploiting the possibilities of e-tail without losing out on the richness and inherent advantages of in-store retail. All retailers will need to develop strategies for responding to enhanced consumer power, possibly with initiatives such as:

i. Marketing via social networking sites

ii. Growing their brand

iii. Differentiating their product offerings

iv. Working hard to ensure that their websites provide consumers with an enjoyable and reliable shopping experience.

The established retailer will also need to consider how they can more effectively integrate their online and off-line channels to provide customers with the very highest levels of service. By contrast, the virtual merchants need to develop strategies for effectively promoting and developing their brands, so that they are in a position to compete on more equal terms with their established, high-street counterparts. These would go a long way in stimulating the efforts of traditional or brick and mortals retailers in facing the challenges of e-tailers hence being in business and keeping their jobs.

\section{REFERENCES}

[1] Babbie, E. (2008). The Practice of Social Research. (12th Edition) Belmont, Ca: Thompson- Wardsworth.

[2] Doherty, N. \& Ellis-Chadwick F. (2010) "Internet retailing: the past, the present and the future", which originally appeared in the International Journal of Retail \& Distribution Management, 38(11/12), 144156

[3] Ernst and Young (2012) Digital Retail, analyzing the effects on retailers. New York: Ernst and Young

[4] Guttman, R. H., (1998), "Agents as Mediators in Electronic Commerce". International Journal of Electronic Markets 8(2), 22-7.

[5] Haubl, G. \& Trifts V (2000), “Consumer Decision Making in Online Shopping Environments: The Effects of Interactive Decision Aids". Marketing Science, 19(1), 4-21.

[6] Hutchings, D, (2015). Global perspective on retail: online retailing 2013; A Cushman \& Wakefield Research Publication. Available from: $<$ http://www.cushmanwakefield.com/en/research-andinsight/2013/globalperspectives-on retail/ accessed on 11th August, 2017

[7] Kalyanam, K., and McIntyre, S (2002), "The EMarketing Mix: A Contribution of the E-tailing Wars. Journal of Academy of Marketing Science", 30(4), 487-499.

[8] McKinsey (2012a). Africa at work: Job creation and inclusive growth. Available from: < https://www.mckinsey.com/ /media/McKinsey/dotco $\mathrm{m} /$ Insights\%20and\%20pubs/MGI/Research/Labor\%20 Markets/Africa\%20at\%20work/MGI_Africa_at_work _August_2016_Executive_Summary.ashx> Accessed on 11th August, 2017

[9] McKinsey (2012b). How retailers can keep up with consumers.

Available from:http://www.mckinsey.com/insights/consumer_an d_retail/how_retailers_can_keep_up_with_consumers Accessed on 11th August, 2017.

[10] Meeker, L. (1997). Retailing Management, $6^{\text {th }}$ edition. New Delhi; Tata McGraw Hill

[11]Plunkett R. (2014): Industry Trends. Journal of Development Affairs. 2(1), 17-23 
[12] Pologeorgis N (2012) The Impact Unpaid Internships Have On The Labor Market. International Journal of Employment Studies. 12(4), 122-131

[13] Price Waterhouse Coopers (2012). What's in Store? 3rd Edition. London: PWC UK

[14] Rao, B. (1999), "The Internet and the revolution in distribution: a cross-industry examination". Technology in Society. 21(1), 287-306.

[15]Ratchford, E (2001), “Internet Retailing Intermediation: A Multilevel Analysis of Inventory Liquidity and Fulfillment Guarantees”, Journal of Business Logistics, 25, 139-170.

[16] Trek J. (2004) Statistics for Beginners, USA: South Western Cengage Learning

[17] Turban, Y.J (2001), “Consumers' Perceived Importance of and Satisfaction with Internet Shopping", Electronic Markets, 11(3), 148-154

[18] Varadarajan, P. R., and Yadav, M. S. (2002), "Marketing Strategy and the Internet: An Organizing Framework". Journal of Academy of Marketing Science, 30(4), 296-312

[19] Wang, E.L (2002). Business research. New York: Macmillan

[20]Zeithaml V.A (2002), "Service excellent in electronic channels", Managing Service Quality, 12(3), 135-138. 